\title{
ANALISIS HUBUNGAN ANTARA HARGA MINYAK MENTAH, EMAS, DAN TIMAH
}

\author{
Kumara Jati \\ Badan Pengkajian dan Pengembangan Perdagangan, Kementerian Perdagangan
}

\begin{abstract}
Abstrak
Artikel ini memberikan analisis pengaruh dari perubahan harga minyak mentah dan emas terhadap perubahan harga timah. Berdasarkan perhitungan Vector Autoregression, dampak dari perubahan harga minyak mentah terhadap harga timah lebih besar dibandingkan dampak dari harga emas terhadap harga timah. Goncangan harga minyak mentah yang terjadi mengindikasikan adanya transmisi harga secara tidak langsung melalui saluran energi, sementara goncangan harga emas terhadap harga timah yang terjadi mengindikasikan adanya transmisi harga secara tidak langsung melalui saluran pertumbuhan ekonomi. Harga timah dan minyak mentah diprediksi pada tahun 2017 mengalami peningkatan. Ini bisa menjadi motivasi bagi pembuat kebijakan publik untuk bisa meningkatkan industri hilir dari timah dengan cara pengembangan produk turunan sehingga sektor usaha lebih kuat dalam berkompetisi dengan negara lain untuk produk timah yang lebih berkualitas dan berkompetisi.
\end{abstract}

Kata kunci: harga timah, harga minyak mentah, harga emas, vector autoregression, kebijakan industri

\section{Abstract}

This article analyzes the impact of crude oil and gold price changes to tin price changes. Based on the calculation of Vector Autoregression, the impact of crude oil price shock to tin price is bigger compare to the gold price shock to tin price. Crude oil price shock to tin price indicates there is indirect price transmission through energy channel, while the gold price shock to tin price indicates there is indirect price transmission through economic growth channel. Tin and crude oil prices predictions in 2017 are expected to increase. It can motivate policy maker to be able to increase the downstream tin products as well as the industrial development of derivatives so that businesses are better equipped to compete with other countries for more qualified and competitive products of tin.

Keywords: tin price, crude oil price, gold price, vector autoregression, industrial policy

\section{Pendahuluan}

Timah adalah salah satu produk komoditi yang potensial di sektor pertambangan dan perdagangan. Permintaan timah di pasar dalam negeri maupun luar negeri terus meningkat secara signifikan dalam bentuk produk setengah jadi maupun produk olahannya (Bappebti, 2013).

Komoditi timah secara fisik di pasar dunia diperjualbelikan melalui Kuala Lumpur Tin Market (KLTM) dan London Metal Exchange (LME). Indonesia juga sudah mempunyai pasar komoditi tersendiri khusus untuk timah di Bursa Komoditi dan Derivatif Indonesia (BKDI). Komoditi timah diperdagangkan di BKDI sejak Agustus tahun 2013. Awalnya pendirian BKDI ingin membuat pasar timah mempergunakan harga di BKDI sebagai referensi, tetapi sampai saat ini LME masih tetap menjadi sumber referensi harga karena LME sudah berdiri sejak tahun 1877 dan memiliki banyak pengalaman serta volume perdagangan komoditi yang tinggi. Berdasarkan laporan LME (2012), spesifikasi kontrak perdagangan komoditi 
timah di LME diperdagangkan 1 lotnya berjumlah 5 ton, dengan jenis metal timah murni $99,85 \%$. Jenis kontrak timah yaitu futures, traded options, TAPOs, dan futures rata-rata bulanan. Jenis industri pengguna timah yaitu industri solder dan timah plat. Semua harga kontrak dalam USD dan dapat diselesaikan pembayarannya menggunakan USD, Poundsterling, Euro dan Yen.

Harga timah internasional yang terbentuk merupakan hasil interaksi dari penawaran dan permintaan timah. Harga ini dipengaruhi oleh jumlah timah yang ditransaksikan. Dari posisi pembeli/ demand, semakin banyak timah yang ingin dibeli maka dapat meningkatkan harga timah. Sementara dari sisi penjual/supply, semakin banyak timah yang ingin dijual maka dapat menurunkan harga timah.

Faktor-faktor yang mempengaruhi sisi supply komoditas timah relatif sulit untuk dikendalikan. Ada banyak penelitian yang sudah dilakukan tentang faktor yang mempengaruhi pembentukan harga komoditas timah, yaitu: permintaan timah, penawaran timah, kondisi ekonomi dunia, persediaan timah dan industri timah di Indonesia (Adeyanju, 2014).

Gambar 1. Harga Timah Internasional di Tahun 1985-2015

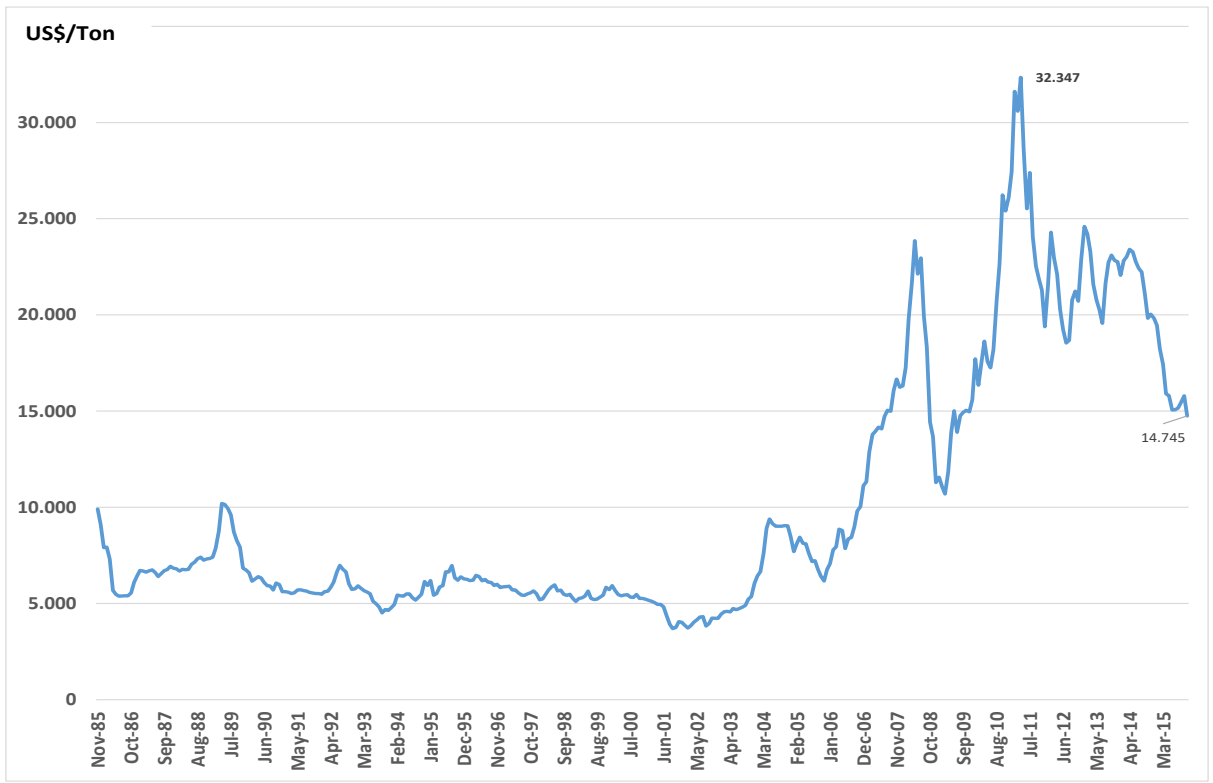

Sumber: World Bank (2015)

Berdasarkan penelitian dari Shanghai Futures Exchange (SHFE, 2014), ada 5 faktor utama yang mempengaruhi harga timah, yaitu: hubungan pasokan dan permintaan, perkembangan ekonomi domestik dan global, kebijakan impor dan ekspor, biaya produksi dan nilai tukar. Gambar 1 memperlihatkan bahwa harga timah dari tahun 1985-2005 relatif stabil, namun harga timah sejak tahun 2006 sampai tahun 2015 relatif berfluktuasi. Salah satu penyebab fluktuasi harga timah yaitu karena pada tahun 2007-2008 terdapat kasus krisis finansial global sehingga pertumbuhan ekonomi dunia menurun. Turunnya pertumbuhan ekonomi ini menyebabkan daya beli dan permintaan akan timah menurun sehingga harga timah juga turun pada tahun 2008. Tahun 2015 juga terjadi perlambatan pertumbuhan ekonomi dunia sehingga menyebabkan permintaan industri terhadap timah berkurang, pada akhirnya membuat harga timah di tahun 2015 cenderung menurun. 
Tabel 1. Harga Timah dan Minyak Mentah Internasional serta Prediksinya di Tahun 2012-2019

\begin{tabular}{|l|c|c|c|c|c|c|c|c|c|c|}
\hline \multicolumn{1}{|c|}{ Harga } & $\mathbf{2 0 1 2}$ & $\mathbf{2 0 1 3}$ & $\mathbf{2 0 1 4}$ & $\mathbf{2 0 1 5}$ & $\mathbf{2 0 1 6}$ & $\mathbf{2 0 1 7}$ & $\mathbf{2 0 1 8}$ & $\mathbf{2 0 1 9}$ & $\begin{array}{c}\text { Perub. } \\
\mathbf{1 9} / \mathbf{1 5} \\
(\%)\end{array}$ & $\begin{array}{c}\text { Tren } \\
\text { (\%) }\end{array}$ \\
\hline $\begin{array}{l}\text { Timah } \\
\text { (ribu USD } \\
\text { / Ton) }\end{array}$ & 19,2 & 20,2 & 19,8 & 14,6 & 15,2 & 17,0 & 18,0 & 17,8 & 21,9 & $-0,02$ \\
\hline $\begin{array}{l}\text { Minyak } \\
\text { Mentah } \\
\text { (USD/ } \\
\text { barrel) }\end{array}$ & 105 & 104,1 & 96,2 & 50,8 & 29,9 & 35,8 & 39,7 & 43,1 & $-15,2$ & $-0,16$ \\
\hline
\end{tabular}

Sumber: EIU Economic and Commodity Forecast (2015) \& IMF Commodity Price Forecasts (2016)

Dari Tabel 1 terlihat bahwa harga timah internasional selama kurun waktu 2012-2015 sebesar rata-rata USD 18.450/ton. Berdasarkan prediksi Economist Intelligence Unit (EIU) Economic and Commodity Forecast harga timah internasional rata-rata untuk tahun 2016-2019 akan turun menjadi USD 17.000/ton. Jadi secara rata-rata harga timah internasional antara tahun 2012-2019 akan menjadi USD 17.725/ton.

Prediksi harga timah ini sebenarnya memberikan secercah harapan karena harga timah pada tahun 2015 sebesar USD 14.600/ton merupakan yang terendah sejak tahun 2009 di mana harga timah hanya USD 13.573/ton. Pada tahun 2016, diharapkan harga timah akan mencapai USD 15.200/ton atau diperkirakan akan terjadi kenaikan sebesar 4,1\% dibandingkan tahun 2015. Peningkatan harga timah juga diperkirakan terjadi pada tahun 2017 dan 2018. Namun pada tahun 2019 diperkirakan harga timah akan turun $1,1 \%$ menjadi USD 17.800/ton dibandingkan 2018. Dalam kurun waktu 8 tahun dari 2012-2019, terjadi tren penurunan harga timah sebesar 0,02. Hal yang hampir sama terjadi pada harga minyak mentah, di mana dalam kurun waktu 8 tahun juga terjadi tren penurunan harga sebesar 0,16 .

Tabel 2. Harga Internasional Timah, Emas dan Komoditi Logam Lain serta Prediksi di Tahun 2016-2023

\begin{tabular}{|l|c|c|c|c|c|c|c|c|c|c|}
\hline Harga & $\mathbf{2 0 1 6}$ & $\mathbf{2 0 1 7}$ & $\mathbf{2 0 1 8}$ & $\mathbf{2 0 1 9}$ & $\mathbf{2 0 2 0}$ & $\mathbf{2 0 2 1}$ & $\mathbf{2 0 2 2}$ & $\mathbf{2 0 2 3}$ & $\begin{array}{c}\text { Perub. } \\
\text { '23/'16 (\%) }\end{array}$ & $\begin{array}{c}\text { Tren } \\
\text { (\%) }\end{array}$ \\
Timah & 18,8 & 19,2 & 19,6 & 20,1 & 20,5 & 21 & 21,5 & 21,9 & 16,5 & 0,02 \\
\hline Emas & 1,22 & 1,21 & 1,19 & 1,18 & 1,16 & 1,15 & 1,14 & 1,12 & 16,6 & 0,02 \\
\hline Nikel & 14,5 & 14,8 & 15,2 & 15,6 & 15,9 & 16,3 & 16,7 & 17,1 & 17,9 & 0,02 \\
\hline Tembaga & 5,9 & 6 & 6,1 & 6,2 & 6,3 & 6,4 & 6,5 & 6,6 & 11,9 & 0,02 \\
\hline Timbal & 1,8 & 1,9 & 1,96 & 2,02 & 2,07 & 2,13 & 2,2 & 2,26 & 25,6 & 0,03 \\
\hline Seng & 2,05 & 2,1 & 2,14 & 2,19 & 2,24 & 2,29 & 2,34 & 2,39 & 16,6 & 0,02 \\
\hline
\end{tabular}

Sumber: World Bank (2015), diolah, satuan ribu USD/ton kecuali emas dalam ribu/troy ounce

Selain EIU (2015) dan IMF (2016), World Bank (2015) juga mengeluarkan prediksi harga internasional timah dan komoditi logam lainnya termasuk nikel, tembaga, timbal dan seng. Harga timah termasuk paling mahal jika dibandingkan dengan komoditi logam lainnya (kategori bukan logam berharga) seperti nikel, tembaga, timbal dan seng. Prediksi dari Bank Dunia ini sedikit berbeda dengan prediksi EIU dan IMF karena tren harga timah diperkirakan 
memiliki tren meningkat dari tahun 2016 sampai dengan tahun 2023.

Peningkatan harga timah selama kurun waktu 8 tahun ke depan ternyata seiring dengan peningkatan harga komoditi logam lainnya dengan tren relatif sama sekitar $0,02-0,03 \%$. Prediksi harga timah dari Bank Dunia relatif lebih tinggi (optimis) dibandingkan dengan prediksi harga timah dari EIU dan IMF dengan perbedaan harga sekitar USD 3.600/ ton di tahun 2016, USD 2.200/ton di tahun 2017, USD 1.600/ton di tahun 2018, dan USD 2.300/ton di tahun 2019. Ekspektasi harga timah tahun 2016-2019 oleh Bank Dunia relatif lebih tinggi dari EIU dan IMF diperkirakan salah satunya karena pertumbuhan konsumsi metal dunia dan konsumsi metal olahan RRT memiliki tren yang terus meningkat.

Perkiraan peningkatan harga komoditi timah dari tahun 2016 ke 2023 relatif lebih rendah dibandingkan peningkatan harga timbal, nikel dan seng. Harga timbal diharapkan naik sebesar $25,6 \%$, harga nikel naik $17,9 \%$, harga seng naik $16,6 \%$ dan harga timah naik sebesar 16,5\%. Apabila harga timah tahun 2023 sebesar USD 21.900 / ton ini benar terjadi maka harga ini merupakan tertinggi timah sejak Agustus 2014 yang sebesar USD 22.231/ton. Namun harga timah sepanjang sejarah tetap tertinggi pada bulan April 2011 yaitu sebesar USD 32.348 /ton.

Pada Gambar 2 terlihat harga minyak di tahun 1980 menyentuh puncak harga tertinggi pada waktu itu. Penulis memprediksi bahwa peningkatan harga ini akan terus terjadi seiring dengan peningkatan permintaan dan berkurangnya cadangan sumber daya alam. Sebaliknya, ada grup ekonom yang berargumen bahwa dalam jangka panjang, teknologi dapat meningkatkan pasokan dengan mengeksploitasi sumber daya alam yang tidak dapat diakses sebelumnya, maka harga komoditi akan jatuh (ATKearney, 2015). Para ekonom ini ternyata benar karena pada tahun 1990an, beberapa harga komoditi seperti timah turun cukup dalam.
Siklus yang menyerupai juga terjadi pada tahun 2008-2009 di mana harga tiga komoditi ini bergerak naik lalu kemudian turun lagi. Begitu juga tahun 2014-2015 terjadi siklus harga komoditi naik kemudian turun lagi. Ada yang menyebut siklus ini sebagai commodity super cycle. Ada beberapa penjelasan mengenai konsep commodity super cycle ini yaitu (Heap, 2005):

(1) Menurut Alan Heap dari Citigroup bahwa super cycle disebabkan oleh pertumbuhan ekonomi yang intensif di RRT.

(2) Super cycle adalah peningkatan trend jangka panjang (selama satu dekade) dari harga komoditi riil yang disebabkan oleh urbanisasi dan industrialisasi dari perekonomian.

(3) Super cycle disebabkan oleh tarikan permintaan.

(4) Ada dua super cycle dalam 150 tahun terakhir yaitu akhir tahun 1800-awal 1990an yang disebabkan oleh pertumbuhan ekonomi di Amerika Serikat, serta dari tahun 1945-1975 sebagai akibat dari rekonstruksi pasca perang di Eropa dan karena kebangkitan ekonomi Jepang.

Penting untuk mempelajari supercycles dari harga komoditi karena sangat menentukan kebijakan pemerintah dan pelaku usaha dalam membuat keputusan produksi, diantaranya (Erten dan Ocampo, 2012): (1) tren dari harga komoditi telah dipertimbangkan sejak waktu yang lama sebagai salah satu isu sentral mengambil kebijakan negara berkembang yang tergantung pada komoditi (seperti di Indonesia), (2) Keputusan untuk meningkatkan kapasitas produksi dengan investasi modal baru juga sangat berpengaruh pada harga saat ini dibandingkan dengan ekspektasi trend harga di masa yang akan datang. Bahkan diperlukan waktu sampai 20 tahun bagi investasi baru untuk berhasil dan menghasilkan realisasi pendapatan (Davis dan Samis, 2006). 
Arah penelitian terbaru mengenai super cycle memberikan sudut pandang yang berbeda. Baffes, dkk (2015), menyebutkan bahwa ada sinyal super cycle telah berakhir karena turunnya harga minyak mentah secara tajam di tengah tahun kedua 2014 setelah harga minyak mentah stabil selama 4 tahun di atas USD 105 per barel. Implikasi dari turunnya harga minyak mentah ini yaitu biaya input turun sehingga harga komoditi lain termasuk timah juga turun.

Gambar 2. Harga Timah, Emas dan Minyak Mentah Dunia

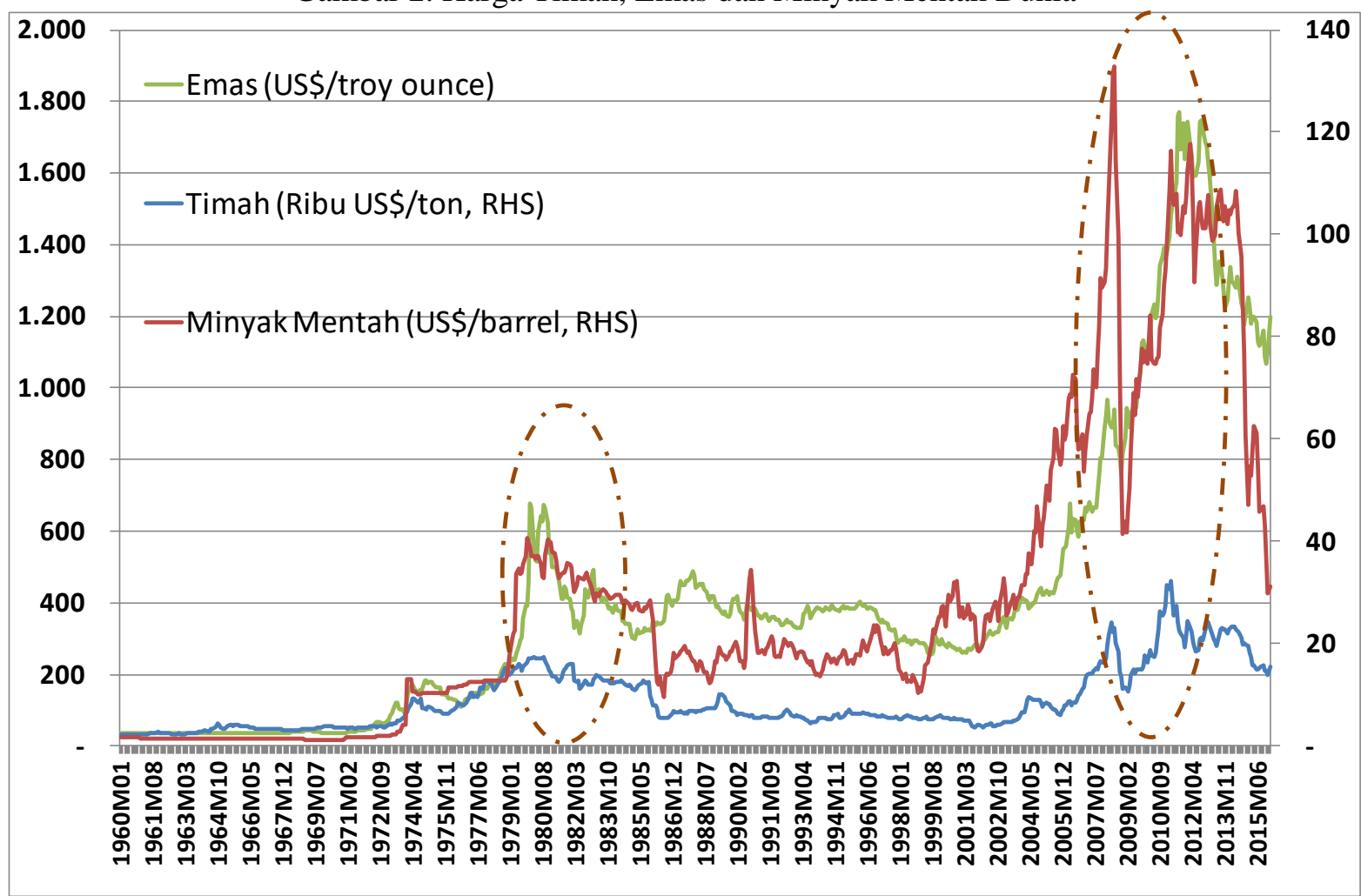

Sumber: World Bank (2016), Comex-CME Group (2016), diolah

Berdasarkan penelitian Harvey (2007), komoditi emas dan komoditi metal (termasuk timah) terindikasi memiliki hubungan jangka panjang meskipun sepertinya hubungan ini akan lebih lemah dibandingkan hubungan minyak mentah dan emas. Pada saat fase ekspansi siklus bisnis, ada peningkatan harga timah dan minyak mentah karena naiknya permintaan keduanya. Meskipun demikian, terlalu tinggi harga minyak mentah juga bisa mengakibatkan aktivitas ekonomi terhambat sehingga mengakibatkan resesi. Arah dari naik atau turunnya harga komoditi energi dan metal sulit diprediksi (Canuto, 2014).
Selain itu ada juga penelitian terbaru dari Sari et al. (2014) yang menganalisis co-movement dan transmisi harga antara metal, minyak mentah dan nilai tukar. Hasilnya yaitu adanya bukti hubungan ekuilibrium jangka panjang yang lemah tetapi feedback yang kuat dalam jangka pendek. Komoditi metal/logam berharga memiliki respon yang signifikan (tetapi sementara) terhadap shock dari logam lain dan nilai tukar.

Sejauh ini ternyata belum ada yang secara khusus membahas mengenai hubungan antara harga timah, minyak mentah dan emas. Maka dari itu, terilhat adanya kesempatan untuk memberikan kontribusi penelitian supaya bisa 
menambah referensi di dunia akademis dan bermanfaat bagi stakeholder terkait.

Dari penjabaran diatas maka tujuan dari penelitian ini yaitu untuk melihat bagaimana hubungan harga komoditi timah, minyak mentah dan emas, terutama shock harga minyak mentah dan emas mempengaruhi harga timah.

\section{Data dan Model yang Digunakan}

Jenis data yang dipergunakan adalah data runtut waktu bulanan periode Januari 1960- Februari 2016 yang diperoleh dari Bank Dunia (harga timah, emas dan minyak mentah). Dalam mengestimasi data tersebut digunakan persamaan VAR untuk variabel harga timah, emas dan minyak mentah ditulis sebagai berikut (hubungan

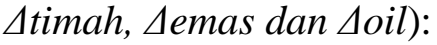

Metodologi

Keterangan:

\begin{tabular}{|c|c|}
\hline Atimah & $=$ persentase pertumbuhan harga timah \\
\hline Lemas & $=$ persentase pertumbuhan harga emas \\
\hline Aoil & $=$ persentase pertumbuhan harga minyak mentah \\
\hline$i$ & $=$ panjang time lag \\
\hline$n$ & $=$ panjang observasi \\
\hline$t$ & $=$ waktu pada saat $\mathrm{t}$ \\
\hline$\alpha_{A 0}, \alpha_{B 0, \text { dan }} \alpha_{C 0}$ & $=$ konstanta \\
\hline $11, \alpha_{A 2,}, \alpha_{A 3 . .} \alpha_{C 3}$ & $=$ koefisien regresi \\
\hline$t, \varepsilon_{B t}$, dan $\varepsilon_{C t}$ & $=$ error term \\
\hline
\end{tabular}

\section{Uji Stasioner}

Sebelum melakukan regresi, variabel-variabel harus bersifat stasioner. Bila variabel tersebut tidak stasioner maka perlu ditransformasi agar stasioner. Suatu data time series dikatakan stasioner jika nilai mean, variance dan autocovariance untuk berbagai lag yang berbeda nilainya adalah konstan sepanjang waktu (Gujarati, 2003):

\section{Model Vector Autoregression (VAR)}

Penelitian dengan time series bisa diestimasi dengan metode estimasi biasa (OLS/Ordinary Least Squares) didasarkan pada asumsi bahwa data tersebut stasioner pada level, artinya data konstan dan independen sepanjang waktu. Meskipun demikian, ternyata sebagian besar data time series merupakan data yang non stasioner. Ini artinya bila menggunakan metode estimasi OLS untuk data non stasioner menyebabkan kegagalan estimasi dalam memperlihatkan nilai-nilai yang sebenarnya (spurious regression) meskipun ukuran sampel diperbesar.

Model ekonometri yang dibentuk dengan menggunakan persamaan simultan biasa merupakan model struktural di mana terdapat hubungan antar variabel yang berdasarkan pada suatu teori tertentu. Meskipun demikian terkadang teori ekonomi sering tidak bisa secara tepat memberikan bentuk spesifikasi untuk hubungan dinamis antar variabel yang tepat. Permasalahan ini memunculkan adanya alternatif model lain yang bersifat 
non-struktural untuk mencari hubungan antar varibel. Pada penelitian ini digunakan model yang disebut Vector Autoregression (VAR).

Model VAR ini, pertama kali diformulasikan oleh Sims (1980), digunakan untuk mengestimasi persamaan simultan dengan menggunakan data time series di mana keseluruhan variabelnya merupakan variabel endogen, sebelah sisi kanan persamaan adalah nilai lag (laggeg value) dari variabel tidak bebas, serta dikatakan vector karena dalam persamaan terdapat suatu vector yang berisi lebih dari dua variabel.

Persamaan VAR yang umum adalah sebagai berikut:

$$
Y_{t}=A_{1} Y_{t-1}+A_{2} Y_{t-2}+\ldots+A_{k} Y_{t-k}+B X_{t}+\varepsilon_{t}
$$

Keterangan:

$$
\begin{array}{ll}
Y_{t} & =\text { matriks } n \times 1 \text { dari variabel endogen } \\
X_{t} & =\text { matriks } m \times 1 \text { dari variabel eksogen } \\
\varepsilon_{t} & =\text { matriks } n \times 1 \text { dari error } \\
A_{1}, A_{2}, \ldots, A_{k}, B & =\text { matriks dari koefisien yang akan diestimasi. } \\
\mathrm{A}_{\mathrm{k}} & =\text { matriks } n \times n \text { dari koefisien variabel endogen yang akan diestimasi } \\
\mathrm{B} & =\text { matriks } n \times m \text { dari koefisien variabel eksogen yang akan diestimasi. }
\end{array}
$$

Selanjutnya model VAR tersebut dikembangkan oleh Enders (1995) dengan memasukkan $A_{0}$ yaitu matriks $n \times 1$ dari intersep tetapi tanpa menggunakan variabel eksogen, persamaannya sebagai berikut:

$$
Y_{t}=A_{0}+A_{1} Y_{t-1}+A_{2} Y_{t-2}+\ldots+A_{k} Y_{t-k}+\varepsilon_{t}
$$

Model VAR bentuk sederhana di atas dengan dua variabel endogen tanpa variabel eksogen dengan jumlah lag=2 adalah dapat ditulis berikut:

$$
\left[\begin{array}{l}
Y_{1, t} \\
Y_{2, t}
\end{array}\right]=\left[\begin{array}{l}
A_{10} \\
A_{20}
\end{array}\right]+\left[\begin{array}{ll}
A_{11} & A_{12} \\
A_{21} & A_{22}
\end{array}\right]\left[\begin{array}{l}
Y_{1, t-1} \\
Y_{2, t-1}
\end{array}\right]+\left[\begin{array}{ll}
B_{11} & B_{12} \\
B_{21} & B_{22}
\end{array}\right]\left[\begin{array}{l}
Y_{1, t-2} \\
Y_{2, t-2}
\end{array}\right]+\left[\begin{array}{l}
\varepsilon_{1, t} \\
\varepsilon_{2, t}
\end{array}\right]
$$

\section{Hasil dan Pembahasan}

\section{Hasil Uji Stasioneritas}

Data yang akan diestimasi dinyatakan stasioner jika nilai rata-rata dan varian dari data time series tersebut tidak mengalami perubahan secara sistematik sepanjang waktu atau rata-rata dan varian dari data itu konstan (Nachrowi dan Usman, 2006). Apabila data dalam model tidak stasioner, maka data itu perlu dilihat kembali kestabilan dan validitasnya. Regresi dari data yang bersifat tidak stasioner dapat menyebabkan spurious regression dimana hasil $R^{2}$ tinggi tetapi hubungan tersebut tidak bisa dijelaskan secara logis.

Tabel 3. Hasil Uji Stasioneritas Augmented Dickey-Fuller (ADF)

\begin{tabular}{|c|c|c|c|}
\hline Variabel & ADF TEST & Mac Kinnon Critical Value & Orde Integrasi \\
\hline$\Delta$ timah & $-18,74^{* * *}$ & $-3,43$ & $\mathrm{I}(0)$ \\
\hline$\Delta$ emas & $-17,62^{* * *}$ & $-3,43$ & $\mathrm{I}(0)$ \\
\hline$\Delta$ oil & $-23,31^{* * *}$ & -3.43 & $\mathrm{I}(0)$ \\
\hline \multicolumn{4}{|c|}{ Keterangan: signifikansi: $5 \%=* *, 1 \% * * *$} \\
Sumber: hasil data diolah
\end{tabular}


Salah satu uji stasioneritas yang sering digunakan yaitu uji akar unit dengan menggunakan Augmented Dickey-Fuller (ADF) test. Tabel 3 memperlihatkan bahwa ketiga variabel stasioner pada orde level. Jadi tidak perlu adanya transformasi/ perubahan orde lagi. Oleh karena itu, karena data sudah stasioner maka bisa langsung dilakukan estimasi Vector Autoregression (VAR).

\section{Estimasi VAR}

Panjang lag yang yang digunakan dalam estimasi VAR pada kelompok bank umum ini adalah lag 2 sesuai dengan penentuan lag yang optimal, dan hasil dari pengolahan datanya sebagai berikut:

Tabel 4. Hasil Estimasi VAR

\begin{tabular}{|c|c|c|c|}
\hline & $\Delta \mathrm{TIMAH}$ & $\triangle \mathrm{EMAS}$ & $\Delta \mathrm{OIL}$ \\
\hline \multirow{3}{*}{$\triangle \mathrm{TIMAH}(-1)$} & 0.254594 & -0.031033 & 0.215799 \\
\hline & $(0.03943)$ & $(0.03658)$ & $(0.08989)$ \\
\hline & $6.45710]$ & {$[-0.84842]$} & [2.40067] \\
\hline \multirow[t]{3}{*}{$\triangle \mathrm{TIMAH}(-2)$} & 0.059771 & 0.001065 & 0.166701 \\
\hline & $(0.03934)$ & $(0.03649)$ & $(0.08968)$ \\
\hline & [1.51946] & [ 0.02919$]$ & [1.85878] \\
\hline \multirow[t]{3}{*}{$\triangle \mathrm{EMAS}(-1)$} & 0.005890 & 0.284589 & 0.245467 \\
\hline & $(0.04266)$ & $(0.03958)$ & $(0.09727)$ \\
\hline & {$[0.13806]$} & {$[7.19024]$} & {$[2.52357]$} \\
\hline \multirow{3}{*}{$\triangle$ EMAS(-2) } & 0.044967 & -0.143262 & -0.255312 \\
\hline & $(0.04253)$ & $(0.03945)$ & $(0.09695)$ \\
\hline & [1.05743] & {$[-3.63142]$} & {$[-2.63339]$} \\
\hline \multirow[t]{3}{*}{$\Delta \mathrm{OIL}(-1)$} & 0.049300 & 0.036389 & 0.069620 \\
\hline & $(0.01727)$ & $(0.01602)$ & $(0.03937)$ \\
\hline & [ 2.85490] & [ 2.27148] & [1.76837] \\
\hline \multirow[t]{3}{*}{$\Delta \mathrm{OIL}(-2)$} & 0.034264 & 0.035499 & -0.012342 \\
\hline & $(0.01740)$ & $(0.01614)$ & $(0.03966)$ \\
\hline & {$[1.96965]$} & [2.19969] & {$[-0.31119]$} \\
\hline \multirow{3}{*}{ C } & 0.195164 & 0.494111 & 0666600 \\
\hline & $(0.19104)$ & $(0.17723)$ & $(0.43554)$ \\
\hline & {$[1.02160]$} & [2.78804] & [1.53051] \\
\hline
\end{tabular}

Sumber: hasil data diolah Eviews 7

Berdasarkan tabel di atas tidak semua variable lag signifikan dalam setiap persamaan. Variabel yang signifikan mempengaruhi perubahan harga timah adalah perubahan harga timah satu bulan sebelum waktu $t$, perubahan harga minyak mentah satu bulan sebelum waktu $t$, dan perubahan harga minyak mentah dua bulan sebelum waktu $t$. 
Minyak mentah merupakan salah satu komponen penting dalam produksi dan distribusi timah. Peningkatan harga minyak mentah 1 bulan sebelum waktu $t$ lebih besar pengaruhnya terhadap harga timah dibandingkan harga minyak mentah 2 bulan sebelum waktu $t$. Hal ini sejalan dengan penelitian dari SHFE (2014), bahwa biaya produksi timah dipengaruhi oleh bahan bakar dan biaya energi.

Perubahan harga emas memiliki pengaruh positif tetapi tidak signifikan terhadap perubahan harga timah. Meskipun pada Gambar 2 terlihat adanya indikasi harga timah dan harga emas bergerak searah, ternyata pada kenyataannya perubahan harga emas tidak cukup kuat mempengaruhi harga timah. Hal ini juga terlihat pada Tabel 2 di mana pada saat prediksi harga emas tahun 2019-2020 menurun, sebaliknya prediksi harga timah tahun 2019-2020 meningkat.

\section{Innovation Accounting (Impulse Response dan Function Variance Decomposition)}

Dalam innovation accounting akan diuraikan bagaimana dan seberapa besar pengaruh shock atau disturbance terhadap variabel-variabel yang dibentuk dalam persamaan. Innovation accounting ini terdiri atas dua bagian yaitu impulse response function (IRF) dan variance decomposition (VDCs). IRF digunakan untuk melihat dampak dari shock di sektor komoditi dalam penelitian ini harga timah oleh perubahan harga emas dan perubahan harga minyak mentah dunia. IRF melacak efek dari salah satu shock ke shock yang lainnya pada saat ini dan masa yang akan datang dari variabel endogen.

Apabila terjadi shock pada variabel ke- $i$ secara langsung maka akan berpengaruh terhadap variabel itu sendiri dan juga merambat ke variabel-variabel endogen yang lainnya melalui struktur dinamis VAR. IRF juga bisa memberikan arah hubungan besarnya pengaruh antar variabel endogen. Maka dari itu shock yang terjadi pada suatu variabel bila mendapat informasi yang baru bisa mempengaruhi variabel itu sendiri serta variabel-variabel yang lainnya dalam sistem persamaan VAR. Berikut disajikan hasil impulse rensponse dari variabel perubahan harga timah terhadap shock dari variabel perubahan harga emas dan harga minyak mentah dunia.

Response to Cholesky One S.D. Innovations \pm 2 S.E. Response of TIMAH to OIL
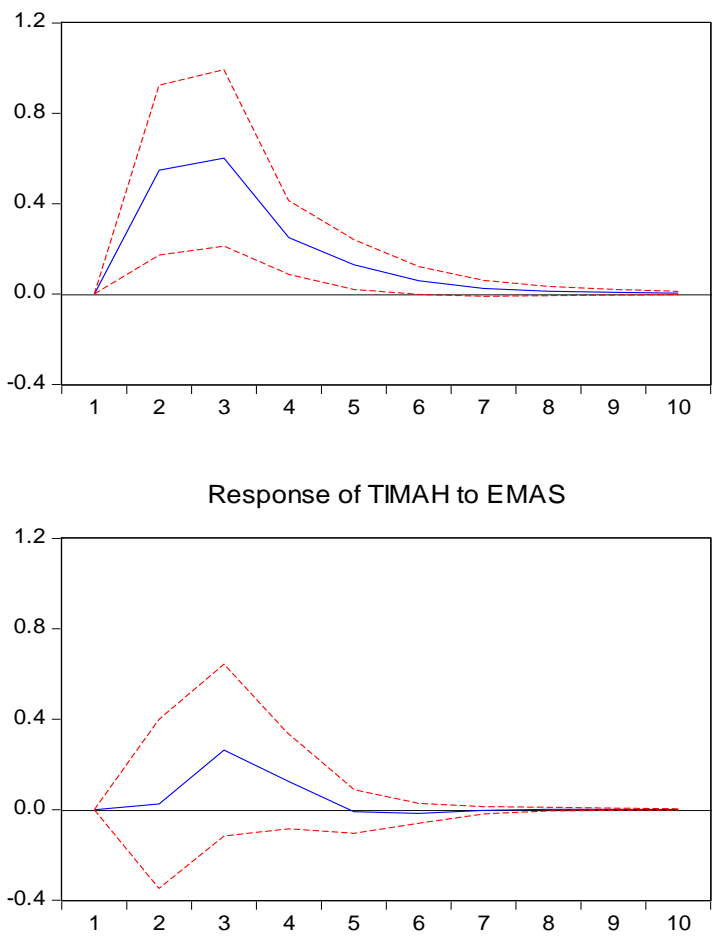

Gambar 3. Impulse Response Function (IRF) pada Variabel Perubahan Harga Timah dari Shock Perubahan harga Emas dan Minyak Mentah

Sumber: Hasil perhitungan software Eviews 7

Dari gambar di atas terlihat bahwa respon dari variabel perubahan harga timah dunia dalam sepuluh (10) periode mendatang apabila terjadi shock pada perubahan variabel harga emas dan minyak mentah dunia, dapat dijelaskan sebagai berikut:

a. Respon variabel perubahan harga timah terhadap shock perubahan harga minyak mentah. Adanya shock pada perubahan harga minyak mentah direspon positif oleh perubahan harga timah dari bulan pertama sampai dengan bulan keenam, dan pada bulan 
ketujuh menuju konvergen. Jadi apabila diasumsikan terjadi shock kenaikan harga minyak mentah dunia dari USD 29,9/barel pada bulan Desember 2016 menjadi USD 35,8/barel pada Januari 2017, maka harga timah diperkirakan akan terkena dampaknya meningkat juga pada bulan Februari, Maret dan April 2017 dengan dampak terbesar terjadi pada bulan Maret 2017 dan dampak kedua terbesar pada bulan Februari 2017. Hal ini mengindikasikan terjadi karena adanya transmisi harga secara tidak langsung melalui saluran energi/energy channel (Serra, 2011).

b. Respon variabel perubahan harga timah terhadap shock perubahan harga emas. Adanya shock pada perubahan tingkat harga emas direspon positif oleh perubahan harga timah pada bulan kedua sampai dengan bulan keempat, dan pada bulan kelima menuju konvergen. Jadi apabila diasumsikan terjadi shock kenaikan harga emas dunia dari USD 2.200 / tray ounces pada bulan Desember 2016 menjadi USD 2.300 / tray ounce pada Januari 2017, maka harga timah diperkirakan akan terkena dampaknya meningkat juga pada bulan Februari, Maret dan April 2017 dengan dampak terbesar terjadi pada bulan Maret 2017 dan kedua terbesar pada April 2017. Hal ini mengindikasikan terjadi karena adanya transmisi harga secara tidak langsung melalui saluran pertumbuhan ekonomi / economic growth channel. Keadaan ini seperti yang terjadi pada penelitian Alexandratos (2008).

Tabel 5. Variance Decomposition pada Variabel Perubahan Harga Timah

\begin{tabular}{|c|c|c|c|c|}
\hline Period & S.E. & TIMAH & EMAS & OIL \\
\hline 1 & 4.866649 & 100.0000 & 0.000000 & 0.000000 \\
\hline 2 & 5.067603 & 98.82670 & 0.054484 & 1.118811 \\
\hline 3 & 5.166774 & 97.25208 & 0.544017 & 2.203902 \\
\hline 4 & 5.187618 & 96.98528 & 0.640499 & 2.374219 \\
\hline 5 & 5.192857 & 96.92847 & 0.639911 & 2.431617 \\
\hline 6 & 5.194165 & 96.91598 & 0.639727 & 2.444294 \\
\hline 7 & 5.194498 & 96.91409 & 0.639651 & 2.446256 \\
\hline 8 & 5.194586 & 96.91359 & 0.639686 & 2.446724 \\
\hline
\end{tabular}

\begin{tabular}{|c|c|c|c|c|}
\hline 9 & 5.194610 & 96.91339 & 0.639715 & 2.446893 \\
\hline 10 & 5.194617 & 96.91333 & 0.639722 & 2.446948 \\
\hline 11 & 5.194618 & 96.91332 & 0.639723 & 2.446962 \\
\hline 12 & 5.194619 & 96.91331 & 0.639723 & 2.446966 \\
\hline \multicolumn{4}{|c|}{ Cholesky Ordering: TIMAH EMAS MINYAK } \\
MENTAH \\
\hline
\end{tabular}

Sumber: hasil perhitungan software Eviews 7

Berdasarkan Tabel 5 di atas bisa diketahui bahwa variabel yang mempunyai prosentase paling besar menjelaskan variabilitas harga timah setelah perubahan harga timah itu sendiri adalah perubahan harga minyak mentah dunia. Pada periode 1 hanya $1,1 \%$, periode 2 dan 3 naik menjadi sekitar 2,2-2,3\%, kemudian perubahan terbesar terjadi pada periode ke 5 dan seterusnya stabil menjadi $2,4 \%$.

\section{Kesimpulan}

Prediksi harga timah dunia pada tahun 2017 akan meningkat berdasarkan prediksi Bank Dunia dan EIU Economic and Commodity Forecast (2015). Hal ini dapat memberikan harapan bagi pembuat kebijakan publik dan pelaku usaha di bidang pertambangan, industri serta perdagangan timah. Pulihnya ekonomi dunia serta meningkatnya permintaan harga timah di masa yang akan datang dapat menjadi faktor penarik harga timah (demand driven) yang bisa diimbangi dengan peningkatan produksi timah dalam negeri.

Setelah melakukan analisis hubungan antara variabel perubahan harga komoditi timah, minyak mentah dan emas maka bisa didapat kesimpulan sebagai berikut: (1) dampak shock perubahan harga minyak mentah terhadap perubahan harga timah lebih besar daripada dampak shock perubahan harga minyak mentah terhadap perubahan harga timah, (2).perbedaan terlihat dari periode kapan respon positif / negatif dan saat menuju konvergen, (3) Shock yang terjadi mengindikasikan adanya transmisi tidak langsung melalui saluran energi dan saluran pertumbuhan ekonomi. 


\section{Rekomendasi Kebijakan}

Pemangku kebijakan terkait industri dan perdagangan timah perlu melihat pergerakan harga minyak mentah serta logam lain khususnya emas karena ada indikasi ketiga harga komoditi ini bergerak searah. Fenomena komoditi super cycle juga perlu diantisipasi karena sangat mempengaruhi kebijakan pemerintah dan keputusan produksi. Kondisi saat ini, di mana harga timah relatif rendah dapat menjadi hambatan bagi pelaku usaha timah karena keuntungan mereka berkurang. Namun demikian, adanya peluang bagi stakeholder untuk bisa meningkatkan hilirisasi produk timah serta pengembangan industri turunnya sehingga pada waktu harga timah naik, pelaku usaha sudah siap bersaing dengan negara lain karena produk timahnya sudah lebih berkualitas dan kompetitif.

Ada 3 rekomendasi kebijakan yang bisa diberikan yaitu: (1) otoritas terkait sebaiknya memacu program hilirisasi melalui industri timah olahan dan pemurnian atau pembangunan smelter karena harga timah yang sudah diolah relatif lebih stabil dari fenomena super cycle dan memiliki nilai tambah yang tinggi. (2) pemangku kepentingan terkait perlu mewaspadai adanya transmisi harga apabila terjadi shok harga minyak mentah dan emas terhadap harga timah yang akan berpengaruh terhadap kelangsungan industri timah secara keseluruhan sehingga perlu dibuat sistem early warning system serta langkah-langkah spesifik yang harus dilakukan terutama jika harga minyak mentah dunia naik / turun secara drastis dalam waktu singkat. (3) perlu adanya review secara berkala terkait kebijakan industri dan perdagangan timah yang sudah ada dengan mengundang seluruh stakeholder sehingga apabila terjadi perubahan kondisi ekonomi makro termasuk asumsi harga minyak mentah atau komoditi lain termasuk emas yang berubah maka beberapa kebijakan juga bisa disesuaikan untuk meningkatkan ease of doing business industri timah dan pertumbuhan ekonomi Indonesia.

\section{Daftar Pustaka}

\section{Buku}

Enders, Walter. 1995. Applied Econometric Time Series. John Wiley \& Sons, Inc. New York.

Gujarati, Damodar N. 2003. Basic Econometrics: Fourth Edition International Edition. McGraw-Hill Higher Education. Singapore.

Nachrowi, Nachrowi. D., Usman, H. 2006. Pendekatan Populer dan Praktis Ekonometrika: Untuk Analisis Ekonomi dan Keuangan. Lembaga Penerbit FEUI. Jakarta.

\section{Artikel}

Adeyanju, Craig. 2014. The Top Factors that Move the Price of Tin. Laporan dari futuresknowledge, diakses pada 18 Februari 2016 dari http://www.futuresknowledge.com/n ews-and-analysis/metals/the-topfactors-that-move-the-price-of-tin/.

Alexandratos, Nikos. 2008. Food Price Surges: Possible Causes, Past Experience, and Longer Term Relevance. Population and Development Review, Vol.34, No.4 (Dec.,2008), pp.663-697.

ATKearney. 2015. Beware the Oil Price Super Cycle. Laporan dari A.T. Kearney, Global Management Consulting Firm.

Baffes, J., Kose, A., Ohnsorge, F., dan Stocker, M. 2015. Understanding the Plunge in Oil Prices: Sources and Implications. Laporan penelitian dari Global Economic Prospects Januari 2015.

Bappebti. 2013. Bursa Timah Rujukan Dunia. Bulletin Bappebti/Mj1/148/XII/2013/Edisi Juli.

Canuto, Otaviano. 2014. The Commodity Super Cycle: Is This Time Different?. 
Laporan penelitian dari World Bank, June 2014, Number 150.

Davis, Graham dan Samis, Michael. 2006. Using Real Options to Manage and Value Exploration, Society of Economic Geologists Special Publication, 12 (14): 273-294.

EIU. 2015. Commodity Market Forecasts. Laporan dari Economist Intelligence Unit (EIU), Economic and Commodity Forecast, diakses pada 18 Februari 2016 dari http://gfs.eiu.com/Article.aspx?articl eType $=$ cf\&articleId $=1354313319 \&$ s ecId $=0$.

Erten, B., dan Ocampo, J.A. 2012. Supercycles of commodity prices since the mid-nineteenth century. DESA Working Paper No.110, ST/ESA/2012?DWP/110, February 2012.

Harvey, J. 2007. Metals-Gold Dips as Dollar Rallies, Oil, Metals Ease. Laporan dari London South East, 25 Juli 2007. Diakses pada 9 April 2016 dari

http://www.lse.co.uk/FinanceNews.a sp?ArticleCode =v2hftahdi039ybi\&A rticleHeadline=Metals__Gold_dips_ as_dollar_rallies_oil_metals_ease

Heap, A. 2005. China-the Engine of a Commodities Super Cycle. Laporan Penelitian Citrigroup Global Markets/Smith Barney, Sydney, Australia.

IMF. 2016. Commodity Price Projections. Laporan dari The International
Monetary Fund (IMF), diakses pada 18 Februari 2016 dari www.imf.org/external/np/res/commo d/data/data0116.xls.

LME. 2012. A Guide to the LME. Report of LME, An HKEX Company.

Sari, R., Hammoudeh, S., dan Soytas, U. 2010. Dynamics of Oil Price, Precious Metal Prices, and Exchange Rate. Energy Economics, Volume 32, Issue 2, March 2010, Pages 351-362.

Serra, T. 2011. Volatility Spillovers Between Food and Energy Markets: A Semiparametric Approach. Energy Economics 33 (2011)1155-1164.

SHFE. 2014. Tin in RRT. Laporan Penelitian dari Shanghai Futures Exchange of RRT, diakses pada 10 Maret 2016 dari http://www.shfe.com.cn/content/nisn-en/gitt.pdf

Sims. Christopher A. 1980. Macroeconomics and Reality. Econometrica. 48, pp.1-48.

World Bank. 2015. Commodity Market Outlook: April 2015. A World Bank Quarterly Report, World Bank Group, diakses pada 28 Maret 2016 dari

https://www.worldbank.org/content/ dam/Worldbank/GEP/GEPcommodi ties/GEP2015b_commodity_Apr201 5.pdf 